DOI: 10.34015/2523-4552.2020.4.16

УДК 347.97/99

Зур'ян В. О.,

молодший спеціаліст у галузі права, здобувач вищої освіти ступеня «Бакалавр» юридичного факультету ВНЗ «Університет економіки та права «КРОК»

ORCID: 0000-0002-0711-8410

\title{
НАГАЛЬНІ ПРОБЛЕМИ ТА ПЕРСПЕКТИВИ РОЗВИТКУ ЕЛЕКТРОННОГО СУДОЧИНСТВА В УКРАЇНІ
}

Стаття присвячена дослідженню проблем електронного судочинства в Україні. Виконано огляд загальних проблем інформатизації суспільства та перспектив впровадження електронного правосуддя. Досліджено процес трансформації юридичної діяльності з усталеної системи до комунікаційної моделі, що передбачає оптимізацію бюрократичної процедури та підвищення ефективності судочинства. Проаналізовано вплив пандемії COVID-19, та пов'язаних з нею карантинних обмежень на прискорення процесів розвитку та впровадженню у судову практику сучасних телекомунікаційних технологій. Обгрунтована неможливість судочинства залишатися осторонь новітніх технологій у сучасних реаліях, а тому розвиток електронного судочинства $\epsilon$ вагомим фактором забезпечення доступності, прозорості та ефективності правосуддя. Окремо досліджено питання запровадження «електронного суду» як самостійної унікальної форми судового процесу, що забезпечують повний цикл розгляду судової справи в електронному форматі. Доведено існування численних ризиків функціонування інформаційного середовища, але вони жодним чином не зменшують значення інформаційних технологій у вдосконаленні державних інститутів.

Ключові слова: електронне судочинство; інформатизація суспільства; електронний документообіг; пандемія COVID-19; автоматизована система документообігу суду.

Статья посвящена исследованию проблем электронного судопроизводства в Украине. Осуществлен обзор общих проблем информатизации общества и перспективы внедрения электронного правосудия. Исследован процесс трансформации юридической деятельности из устойчивой системы в коммуникационную модель, предполагающую оптимизацию бюрократической процедуры и повышение эффективности судопроизводства. Проанализировано влияние пандемии COVID-19, и связанных с ней карантинных ограничений на ускорение процессов развития и внедрения в судебную практику современных телекоммуникационных технологий. Обоснована невозможность судопроизводства оставаться в стороне передовых технологий в современных реалиях, а потому развитие электронного судопроизводства является весомым фактором обеспечения доступности, прозрачности, а также эффективно- 
сти правосудия. Отдельно исследован вопрос внедрения «электронного суда» как самостоятельной уникальной формы судебного процесса, обеспечивающего полный цикл рассмотрения дела в электронном формате. Доказано наличие многочисленных рисков функционирования информационной среды, но они никоим образом не уменьшают значение информационных технологий в усовершенствовании государственных институтов.

Ключевые слова: электронное судопроизводство; информатизация общества; электронный документооборот; пандемия COVID-19; автоматизированная система документооборота суда.

Постановка проблеми. Сучасна, передова держава не може повноцінно існувати без функціонування швидкої та відкритої системи судочинства. Проте на сьогоднішній день загальний стан автоматизації судової системи України не можна вважати цілком задовільним. Натомість, впровадження у неї новітніх інформаційно-комунікаційних технологій дозволить підвищити ефективність судочинства в умовах всеоб'ємлючого зростання інформатизації суспільства. Це, у свою чергу, дозволить дотримуватися відповідних передових принципів, засад, і стандартів електронного судочинства.

Електронне правосуддя не $\epsilon$ чимось абсолютно новим для українського цивільного судочинства на даний час. Першим кроком щодо запровадження електронного правосуддя можна назвати включення у ЦПК України ст. 197 про фіксування цивільного процесу технічними засобами [1]. Далі у 2012 р. розвиток електронного правосуддя продовжився через закріплення відповідної норми (ст. 158-1 ЦПК України) про участь учасників процесу у судовому засіданні в режимі відеоконференції. Серед останніх досягнень електронного правосуддя важливим $€$ реалізація проекту щодо обміну електронними документами між судом та учасниками судового процесу, відпо- відно до Розділу 4 «Надсилання електронних документів судом Користувачу» Тимчасового регламенту надсилання судом електронних документів учасникам судового процесу, кримінального провадження [2].

На відміну від України електронне правосуддя в більш розвинених країнах $€$ достатньо поширеним та широко застосовуваним, оскільки це сприяє реалізації принципу доступності правосуддя через спрощення роботи усіх суб'єктів судочинства, пришвидшення строків розгляду спору та усунення транскордонних бар'єрів в межах держав-членів при здійсненні судочинства. Основні стандарти щодо електронного правосуддя в Євросоюзі передбачені у наступних документах: Рекомендаціях Комітету міністрів Ради Європи державам-членам стосовно відбору, оброблення, подання та архівації судових рішень у правових інформаційно-пошукових системах; Рекомендаціях (2001) 3 Комітету міністрів ради Європи державам-членам щодо надання судових та інших юридичних послуг громадянам з використанням новітніх технологій; Рекомендаціях (2003) Комітету міністрів ради Європи державам-членам про архівування електронних документів у правовій сфері та інші. На даний час в ЄC відбувається реалізація Плану дій щодо електронного правосуддя [3]. 
Тут варто одразу вказати, що в Україні також прийнята Концепція електронного суду України, в якій розглядаються питання шляхів побудови, удосконалення та перспектив універсальних форматів взаємодії систем документообігу та діловодства [4].

Аналіз останніх досліджень і публікацій. Теоретико-прикладні аспекти інформаційної політики, значення інформаційних технологій у різних сферах суспільного життя, питання інформаційно-технічного забезпечення діяльності окремих органів державної влади досліджені і описані в роботах науковців-правників, серед яких Г. В. Атаманчук, П. М. Бірюков, . Є. Сімсон, В. С. Цимбалюк та ін. Питанням електронного судочинства як окремого напрямку електронного урядування останнім часом також приділяють увагу все більше вітчизняних дослідників. серед них I. О. Боголюбський, М. В. Бондаренко, I. В. Булгакова, О. В. Головченко, I. О. Ізарова, І. А. Каланча та інші.

Дослідження використання передових досягнень зазначених технологій в аспекті електронного судочинства $\epsilon$ фрагментарними, присвяченими переважно окремим аспектам цієї проблеми. Такі обставини свідчать про відсутність комплексного підходу до розробки проблеми впровадження електронно-інформаційних технологій у судову діяльність і обумовлюють неповноту іï вирішення особливо в умовах сучасних викликів до суспільства.

Постановка завдання. Виконати аналіз нормативно-правової бази України, що регулює діяльність електронного судочинства в період карантинних обмежень, зумовлених пандемією COVID-19. Проаналізувати досвід впровадження в практику судочинства штучного інтелекту. Запропонувати шляхи вирішення зазначених проблем, та окреслити перспективи подальшого розвитку електронного судочинства в Україні 3 урахуванням досвіду отриманого під час роботи судочинства в період пандемії COVID-19.

Виклад основного матеріалу. Стрімкий розвиток інформаційних технологій у XXI-му столітті ставить принципово нові виклики та завдання перед українськими законодавцями, зокрема, у галузі судочинства. Така необхідність зумовлена, в першу чергу, відповідністю національного законодавства передовим світовим нормам, що дозволить суб'єктам права зручніше користуватися адміністративними послугами. Досліджуючи проблематику впровадження повноцінного електронного судочинства, перш за все слід звернути увагу на цілеспрямовану цифровізацію вітчизняного судочинства шляхом прийняттям Положення про автоматизовану систему документообігу суду (АСДС), що $є$ основним нормативно-правовим актом, який регулює діяльність електронного судочинства. Дане положення було розроблено та затверджено на виконання вимог пункту 17 Перехідних положень Закону України «Про судоустрій і статус суддів», та ін. нормативно-правових актів [5]. Цей нормативний документ регулює відносини, пов'язані 3 функціонуванням автоматизованої системи документообігу суду відповідно до Законів України в галузі інформаційно-телекомунікаційної політики [6].

Чинна нормативна база дозволяє констатувати поступовий пере- 
хід українського судочинства 3 усталеної «паперової» моделі (людина-людина) до електроннокомуніка-ційної системи, де провідну роль починає відігравати взаємодія людини та машини. Виражено це, першочергово, у повсякденності застосування автоматизованої системи документообігу суду, де необхідні практичні знання користувача задля отримання необхідного результату. Також не можна відкидати значення морального фактору кожної людини, адже одній особі буде легко перелаштуватися на користування будь-якою інновацією, інша же вважає за необхідне дотримуватися усталеного звичаю ділового обороту. Тому законодавець, шляхом видання відповідних нормативних актів, зобов'язувати осіб користуватися електронною діловою документацією, що має вираження, наприклад, Розділі III Положення про АСДС [7]. Така імперативна політика держави викликана необхідністю постійної оптимізації бюрократичної процедури та підвищення ефективності українського судочинства.

Особливо актуальним питання застосування електронного (дистанційного) судочинства постало після введення законодавчих карантинних обмежень, спрямованих на запобігання виникненню і поширенню коронавірусної хвороби (COVID-19), відповідно до Закону України від 17.03.2020 № 530-IX. Однак, протягом дії обмежень, та із їх послабленням, судова система знову повернулася до звичного їй ритму очного судочинства (не дивлячись на небезпечну епідеміологічну ситуацію), хоч i не без зрушень в сторону дистанційної форми.
Варто відзначити високу вірогідність посилення карантинних обмежень у зв'язку із погіршенням ситуації з COVID-19. Якщо дані міри будуть застосовані, слід очікувати інтенсивнішу цифровізацію судового документообігу, зокрема у світі. Для України це буде означати необхідність в подальшому знову наздоганяти світові тенденції та впроваджувати вже розроблені інновації. Це, у свою чергу, зумовлене практичною необхідністю доступного судового процесу. Саме тому судочинство не може залишатися осторонь новітніх інформаційно-телекомунікаційних технологій: від його зручності (як для суб'єктів права, так і державних службовців) прямо залежить ефективність та дієздатність всієї судової галузі держави.

Випадки окремого застосування штучного інтелекту якого вже існують в практиці судочинства (наприклад, автоматизована стенографія). Однак, слід відзначити високу можливість остаточного застосування штучного інтелекту на заміну таким професіям у суді, як, наприклад, секретар судового засідання. Враховуючи права та обов'язки, якими наділений представник цієї посади, вже на даному етапі розвитку автоматизації можна наділити роботизовану систему такими повноваженнями як:

- судові виклики та повідомлення;

- перевірка наявності та відсутності осіб;

- фіксування судового засідання технічними засобами;

- ведення журналу судового засідання;

- направлення копій судових рішень;

- виписка виконавчого листа; 
- оформлення матеріалів судових справ;

- підготовка інформації щодо справ, призначених до розгляду;

- дотримання внутрішнього трудового розпорядку.

Розглянутий вище матеріал підводить до того, що постає питання: чи можливий цілковитий перехід від наявної системи «людина-машина» до «машина-машина»? Закордонний досвід застосування штучного інтелекту у судочинстві можна побачити, наприклад, у Російській Федерації: розроблена інновація була представлена у тестовому вигляді наприкінці 2018 р. Робот-стенографіст, за умови професійного керування секретарем, здатний майже вдвічі скоротити час підготовки протоколу судового засідання. Окрім того, дана розробка має можливість автоматично складати протоколи із вкладенням аудіо- та відеозапису, включно з учасниками, виступаючими по відеозв'язку. Також система дозволяє автоматично транслювати перебіг засідання в мережу Інтернет. Ї̈̈ повсюдне застосування у російських судах розпочалося у 2019 р. [8]. А вже на початку грудня 2020 р. була введена інновація, за допомогою якої учасники судового процесу зможуть отримати інформацію щодо справи автоматичним голосовим довідником [9].

У Китайській Народній Республіці пішли ще далі: у тому ж 2018 р. було проведене судове засідання за головуванням судді, змодельованої за допомогою нейромережі. Друге засідання, що відбулося за таким же принципом, мало місце у 2020 р. 3 початку 2019 р. в судах країни вже не раз використовувалася допомогу штучного інтелекту, але участь «розумних» програм включала тільки надання доказів у справі (у вигляді документації), а також допомогу в проведенні досліджень [10].

Також слід звернутися до наявного досвіду Сполучених Штатів Америки, де нещодавно 3'явилися програми «передбаченого правосуддя» (далі - ПП), що походить від англійського словосполучення «Predicting justice». На даний час з'явилися програми, які передбачають результат судових процесів, включаючи потенційну компенсацію. «LegalTech», як дані програми позначаються у зарубіжній літературі [11], пропонує багато переваг: автоматизація повторюваних завдань для юристів, не відволікання уваги юристів на малозначні задачі, зниження судового ризику і т. д.

Так, в ужиток увійшло нове поняття - «передбачене правосуддя», що спирається на штучний інтелект, надаючи юристам інструменти, що дозволяють їм зосередитися на складніших задачах [12].

У той час як традиційне правосуддя намагається виконати свою місію - в розумні терміни винести рішення по справі, ПП йде далі. Воно надає алгоритми для аналізу в короткі терміни величезного кількості ситуацій, які дозволяють передбачити результат суперечки або, принаймні, оцінити шанси на успіх. ПП дозволяє: обрати найбільш правильний спосіб захисту, вибрати найбільш підходящі аргументи; оцінити передбачувану суму компенсації тощо.

Таким чином, мова йде не про саме правосуддя, а лише про аналітичні інструменти, які дозволяють прогнозувати майбутні рішення в суперечках на основі проаналізованих раніше. 
Професор Б. Дондеро в зв'язку з цим підкреслює, що ПП «це спроба 3 мінімальною невизначеністю передбачити, якою буде відповідь юрисдикції X при розгляді справи Ү» [13, c. 331].

У цей же час, країни ЄС вже впроваджують нормативні положення щодо регулювання використання штучного інтелекту в судах. Зокрема, прийнята «Хартія щодо використання штучного інтелекту у судових системах та оточуючих їх реаліях». Ця Хартія визначає основні принципи щодо використання штучного інтелекту [14]:

1. Принцип дотримання основних прав: забезпечити розробку i впровадження інструментів та послуг, заснованих на штучному інтелекті, що відповідають Конвенції про права людини, та Конвенції про захист персональних даних.

2. Принцип недискримінації: певним чином перешкоджати розвитку або посиленню будь-якої дискримінації між особами.

3. Принцип якості та безпеки: при обробці судових рішень і даних використовувати сертифіковані джерела й нематеріальні дані із застосуванням моделей, розроблених на міждисциплінарній основі в безпечної технологічному середовищі.

4. Принцип прозорості, неупередженості та достовірності: зробити методи обробки даних доступними та зрозумілими, дозволити проведення зовнішнього аудиту.

5. Принцип контролю користувачем: уникнути наказуючого підходу, та дозволити користувачеві виступати в ролі обізнаної особи, відповідальної за свій вибір.

Проте, нині часткова, або повна заміна людей у судовому процесі роботами, чи роботизованими істотами не представляється можливою. Людські риси, такі як: моральні цінності, риторика, аргументація фактами, інше - всім цим має бути наділений штучний інтелект. Крім того, у цьому випадку законодавцям-людям необхідно, перш за все, розробити теорію у вигляді законодавчих норм (роботизоване право, наприклад), які будуть покликані регулювати відносини автоматичної системи та людини, а також автоматів між собою. Не слід забувати, що використання програм, подібних до «передбачуваного правосуддя» $\epsilon$ більшою мірою експериментальним. Хоча його рішення беруться до уваги, все одно трапляються ризиковані випадки, адже машина так само не застрахована від помилки, як і людина.

Тим не менш, позитивним чинником автоматизації судового процесу, безумовно, є зменшення навантаження на конкретну людину, себто державного службовця. У випадку України, де існує нестача суддівського персоналу усіх ланок, прогресує перевантаженість судів. Особливо це стосується установ першої та апеляційної інстанцій. Певною мірою вирішити цю проблему зможе законопроект № 4360 «Про внесення змін до деяких законодавчих актів щодо забезпечення належного повідомлення учасників судового процесу та направлення копій судових рішень», який дозволить відправляти судові рішення та повістки електронною поштою, або за телефонним номером. Однак, загалом українська державна політика у галузі судочинства не направлена на його полегшення, а такі пропозиції народних депутатів мають спорадичний характер. 
Проте вдосконалення державних інститутів напряму залежить від ступеня розвитку інформаційнокомунікаційних технологій. У певному сенсі, держава - така ж машина, система, як і робот. А тому, в контексті взаємовідносин «машина-машина» варто розглядати не тільки роботизованих учасників судового процесу, а ще й державу, як основного гаранта дотримання прав і свобод, якщо можна так сказати, цих самих роботів. Достеменно невідомо, що чекає на людство у майбутньому, однак вже на даний час можна з упевненістю констатувати: розвитку автоматизованого судочинства - бути!

Висновки. Доведено, що українське судочинство не може залишатися осторонь новітніх техноло- гій у сучасних реаліях, а тому розвиток електронного судочинства $\epsilon$ вагомим фактором забезпечення доступності, прозорості та ефективності правосуддя. Встановлено, що Україна поступово впроваджує світові здобутки інформаційних технологій у вітчизняну систему судочинства. Разом з тим дані нововведення все одно проходять через призму ускладненої бюрократичної процедури. Обгрунтовано, що пандемія COVID-19, та пов'язані 3 нею карантинні обмеження суттєво прискорили процеси розвитку та впровадження у судову практику сучасних телекомунікаційних технологій.

\section{Список використаних джерел}

1. Цивільний процесуальний кодекс України: Кодекс України; Кодекс, Закон від 18.03.2004 № 1618-IV. Дата оновлення: 13.08.2020. URL: https://zakon.rada.gov.ua/laws/show/ru/1618-15/conv\#Text (дата звернення: 20.09.2020).

2. Про затвердження Тимчасового регламенту надсилання судом електронних документів учасникам судового процесу, кримінального провадження: ДСА України; Приказ, Регламент от 07.11.2016 № 227. URL: https://zakon.rada.gov.ua/ rada/show/ru/v0227750-16/conv\#n17 (дата звернення: 20.10.2020).

3. Multiannual European E-Justice Action Plan 2014-2018. Official Journal of the European Union: June 14, 2010. URL: https://eur-lex.europa.eu/legal-content/ EN/TXT/PDF/?uri=CELEX:52014XG0614(01)\&from=EN (дата звернення: 21.09.2020).

4. Концепція електронного суду України: концепція / Державне підприємство «Інформаційні судові системи». Київ, 2012. URL: https://ukbs.org.ua/ files/koncept_digital_ukr.pdf (дата звернення: 21.09.2020).

$5,6,7$. Щодо Положення про автоматизовану систему документообігу суду: Рада суддів України; Решение, Положение, Распоряжение [...] от 26.11.2010 № 30. Дата оновлення: 17.07.2020. URL: https://zakon.rada.gov.ua/rada/show/vr030414-10/ conv?lang=ru\#Text_(дата звернення: 22.10.2020).

8. Суд: встать, робот идёт: в российские суды посадят роботовстенографистов. Российская газета - Федеральный выпуск № 274 (7737) от 05.12.2018. URL: https://rg.ru/2018/12/05/v-rossijskie-sudy-posadiat-robotov-stenografistov.html (дата звернення: 22.10.2020).

9. Участники судебного процесса смогут получать информацию о деле у автоматического голосового помощника. Федеральное государственное бюджетное учреждение «Информационно-аналитический центр поддержки ГАС «Правосудие» 
(ФГБУ ИАЦ Судебного департамента). URL: http://iac.cdep.ru/index.php?id=9\&item=213 (дата звернення: 22.09.2020).

10. У Китаї вперше провели судове засідання, на якому функцію судді виконував ШІ. Інтелектуальні машини. URL: https://www.everest.ua/u-kytayi-vpersheprovely-sudove-zasidannya-na-yakomu-funkcziyu-suddi-vykonuvav-shi/ (дата звернення: 22.10.2020).

11. Goodman B., Harder J. Four areas of legal ripe for disruption by smart startups. ABA Journal. December 16, 2014. № 12. URL: https://www.lawtechnologytoday.org/ 2014/12/smart-startups/ (дата звернення: 22.10.2020).

12. Predicting justice: what if algorithms entered the courthouse? The Conversation. April 24, 2018 URL: https://theconversation.com/predicting-justice-what-ifalgorithms-entered-the-courthouse-91692 (дата звернення: 22.10.2020).

13. Бирюков П. Н. Деятельность США в сфере использования искусственного интеллекта. Международное и европейское право. 2019. № 3. С. 331.

14. Европейская этическая хартия об использовании искусственного интеллекта в судебных системах и окружающих их реалиях: принята на 31-м пленарном заседании ЕКЭП (Страсбург, 3-4 декабря 2018 года). C. 8. URL: https://rm.coe.int/ruethical-charter-en-version-17-12-2018-mdl-06092019-2-/16809860f4 (дата звернення: 23.10.2020).

\section{References}

Goodman, B., Harder, J. (2014). Four areas of legal ripe for disruption by smart startups. ABA Journal, 12.

Biryukov, P. (2019). Deyatelnost SShA v sfere ispolzovaniya iskusstvennogo intellekta. Mezhdunarodnoe i evropejskoe pravo, 3, 331-335 [in Ukrainian].

V. Zuryan, Law Associate Degree, Student of the Faculty of Law, University of Economics and Law "KROK"

ORCID: 0000-0002-0711-8410

\section{Current problems and prospects for the development of electronic legal proceedings in Ukraine}

The article is devoted to the study of the problems of electronic legal proceedings in Ukraine. The general problems of informatization of society and the prospects for the introduction of electronic justice are reviewed. The process of transformation of legal activity from a stable system into a communication model, which involves the optimization of bureaucratic procedures and an increase in the efficiency of legal proceedings, has been investigated. The impact of the COVID-19 pandemic and related quarantine restrictions on accelerating the development processes and implementation of modern telecommunication technologies into judicial practice is analyzed. The impossibility of legal proceedings to remain on the side of advanced technologies in modern realities is substantiated, and therefore the development of electronic court proceedings is a significant factor in ensuring accessibility, transparency, and also the efficiency of justice. The issue of introducing "electronic court" as an independent unique form of judicial process, 
providing a full cycle of consideration of a case in electronic format, has been separately investigated. The presence of numerous risks of the functioning of the information environment has been proven, but they in no way diminish the importance of information technologies in improving state institutions.

Keywords: electronic legal proceedings; informatization of society; electronic document management; electronic record keeping; COVID-19 pandemic; automated court document management system. 